\title{
PENGARUH PENDAPATAN ASLI DAERAH (PAD) DAN DANA ALOKASI KHUSUS (DAK) TERHADAP ALOKASI BELANJA MODAL PADA KABUPATEN/KOTA PEMERINTAH PROVINSI ACEH TAHUN 2014-2018
}

\author{
Ikhyanuddin $^{1}$, Fuadi $^{2}$, Nanda Safitri ${ }^{3}$ \\ ${ }^{1,3}$ Prodi Akuntansi Fakultas Ekonomi dan Bisnis Universitas Malikussaleh Lhokseumawe \\ ${ }^{2}$ Prodi Ekonomi Pembangunan Fakultas Ekonomi dan Bisnis Universitas Malikussaleh Lhokseumawe \\ $\underline{\text { ikhyanuddin@unimal.ac.id }}^{1}$
}

\begin{abstract}
This study aimed to determine the effect of the knowledge of board member about the budget on the supervision of regional finances with the transparency of public policy and accountability as moderating variables. The samples of this study were taken using Census sampling technique in which the entire population used as the sample. Questionnaires were distributed as many as 45 questionnaires and returned 39 questions, then analyzed using Moderated Regression Analysis and the hypothesis were tested using SPSS. The results of this study showed that the knowledge of board members about the budget had a significant positive effect on the supervision of regional finances. The knowledge of board member of budgets with the transparency of public policy as moderating variable influence negatively on the supervision of regional finance. The results of this test indicate that the Transparency of Public Policy weakened the relationship between the knowledge of board members about budgets to the supervision of regional finances. The knowledge of board members about budgets with accountability as a moderating influenced the supervision of regional finances, the results of these tests explained that accountability strengthened the relationship of knowledge of board members on budgets toward the supervision of regional finance. Simultaneous test ( $f$-test) indicated that the knowledge of board members about budgets influenced the supervision of regional finance with the transparency of public policy and accountability as moderating variables that can be seen with the value of sig 0,029 that is less than 0,05 so that the hypothesis was accepted.
\end{abstract}

Keywords: Local Financial Supervision; Knowledge of Board Members about Budgets; Transparency of Public Policy; Accountability.

\section{PENDAHULUAN}

Sejak diberlakukannya otonomi daerah, Kabupaten dan Kota memiliki hak dan kewenangan yang lebih luas. Seperti tercantum dalam Undang-Undang Nomor 32 Tahun 2004 tentang Pemerintahan Daerah, bahwa yang dimaksud dengan otonomi daerah yaitu hak, wewenang, dan kewajiban daerah otonom dalam mengatur dan mengurus pemerintah dan kepentingan masyarakat setempat yang diatur dalam peraturan perundang-undangan.

Dalam rangka untuk mendukung supaya terlaksananya otonomi daerah yang optimal, maka diberlakukanlah perimbangan keuangan antara pemerintah pusat dengan pemerintah daerah. Perimbangan keuangan ini diatur dalam UndangUndang Nomor 33 Tahun 2004 tentang Perimbangan Keuangan Daerah. Desentralisasi fiskal yang diatur dalam Undang-Undang Nomor 33 tahun 2004 terdiri dari pajak daerah (tax assignment), dana bagi hasil (revenue sharing), dana alokasi umum, dan dana alokasi khusus. Dengan adanya desentralisasi fiskal ini, Pemerintah daerah diharapkan mampu mengoptimalkan penerimaan daerahnya sehingga dapat mandiri dalam pengelolaan keuangannya dan dapat mengurangi ketergantungan terhadap pemerintah pusat.

Tujuan utama dalam pelaksanaan kegiatan otonomi daerah adalah untuk meningkatkan pelayanan kepada publik (publik service) dan memajukan perekonomian daerah di Indonesia. Pelaksanaan otonomi daerah dan desentralisasi fiskal, pada dasarnya terkandung tiga misi utama yaitu meningkatkan kualitas dan kuantitas pelayanan publik dan kesejahteraan bagi masyarakat, menciptakan efisiensi dan efektifitas dalam pengelolaan sumber daya daerah, dan menciptakan ruang bagi masyarakat (publik) untuk berpatisipasi dalam hal pembangunan (Mardiasmo, 2009:59).

Pemerintah daerah dalam mengalokasikan dana dalam bentuk anggaran belanja modal tujuannya untuk menambah aset tetap atau investasi yang ada sehingga akan memberikan manfaatnya tersendiri pada periode tertentu. Didalam struktur APBD, belanja modal berada dalam urutan setelah belanja operasi yang terdiri dari belanja pegawai, belanja barang dan jasa, belanja bunga, belanja subsidi, belanja hibah, dan belanja bantuan sosial (Peraturan Pemerintah Nomor 12 Tahun 2019). Dimana belanja modal merupakan suatu pengeluaran yang dapat 
dikatakan sebagai pengeluaran rutin dalam rangka pembentukan modal yang ada. Dalam hal ini pembelanjaan belanja modal yang dimaksud dapat berupa tanah, peralatan dan mesin, gedung dan bangunan, jalan, irigasi dan jaringan maupun dalam bentuk fisik lainnya. Pemanfaatan belanja lebih baik dialokasikan untuk hal yang bersifat produktif misalnya untuk melakukan aktifitas pembangunan, kemudian penerimaan pendapatan pemerintah hendaknya lebih besar digunakan untuk program pelayanan publik, pendapat ini mengungkapkan bahwa pentingnya mengalokasikan belanja untuk berbagai kepentingan kepada publik (Hendri Paulus Gerungan et al., 2015).

Dalam Peraturan Pemerintah Nomor 71 Tahun 2010 tentang Standar Akuntansi Pemerintah aset tetap yaitu aset berwujud yang mempunyai masa manfaat lebih dari 12 (dua belas) bulan untuk digunakan dalam kegiatan pemerintah atau dimanfaatkan oleh masyarakat umum. Aset tetap yang dimiliki oleh pemerintah daerah dari belanja modal merupakan syarat utama untuk mendukung dalam memberikan pelayanan publik. Untuk menambah aset tetap, pemerintah daerah mengalokasikan dana dalam bentuk anggaran belanja modal sesuai dengan prioritas anggaran dan pelayanan publik baik itu dalam bentuk infrastruktur, peralatan, maupun dalam bentuk sarana dan prasarana sehingga dapat memberikan dampak jangka panjang secara finansial.

Provinsi Aceh merupakan salah satu daerah yang diberikan otonomi khusus oleh pemerintah pusat melalui Undang-Undang Nomor 18 Tahun 2001 tentang Otonomi Khusus bagi Provinsi Daerah Istimewa Aceh sebagai Provinsi Nanggroe Aceh Darussalam. Proporsi pendapatan untuk sumber daya minyak dan gas adalah $70 \%$. Ketetapan ini melebihi otonomi biasa yang mengatur pembagian pendapatan untuk provinsi hanya $15 \%$ dari minyak serta $30 \%$ dari gas. Pemberian otonomi dan proporsi pendapatan yang cenderung besar ini diharapkan dapat melakukan pembangunan ekonomi dan pertumbuhan ekonomi Kabupaten/Kota Provinsi Aceh yang jauh tertinggal dibandingkan dengan kemajuan ekonomi provinsi lain di Indonesia, selanjutnya pencapaian tersebut dapat memberikan kesejahteraan bagi masyarakat umum. Provinsi Aceh dengan luas wilayah $57365,57 \mathrm{~km}^{2}$ dan terdiri dari 18 kabupaten dan 5 (lima) kota merupakan daerah dengan struktur geografi dan kultur sosial ekonomi masyarakat yang berbeda. Kondisi ini yang menyebabkan proses pembanguanan daerah atau kabupaten/kota pada provinsi Aceh menunjukkan dinamika yang relatif berbeda antara satu dengan lainnya.

Permasalahan yang terjadi dalam pemerintah daerah pada organisasi sektor publik yaitu mengenai pengalokasian anggaran. Dimana pengalokasian anggaran adalah jumlah alokasi dana untuk masingmasing kegiatan. Dengan sumber daya yang sangat terbatas pemerintah daerah harus mampu mengalokasikan penerimaan pendapatan yang bersifat produktif yang dialokasikan secara adil dan merata supaya dapat dinikmati oleh semua masyarakat khususnya dalam pemberian pelayanan umum. Dengan demikian pemerintah daerah harus mampu dalam menggunakan sumber-sumber pendapatan daerah dalam hal pelayanan publik yaitu dengan mengalokasikan sumber-sumber pendapatan daerah kedalam belanja modal (Kawendar et al., 2008).

Namun fenomena yang terjadi selama ini pemerintah daerah dalam hal belanja modal belum mendapat perhatian yang serius dari Pemerintah Aceh, baik pemerintah pusat maupun pemerintah daerah. Sehingga kedepan hendaklah lebih intensif diperhatikan dan diprioritaskan, karena pada kenyataannya selama ini anggaran pemerintah baik APBN maupun APBD lebih besar porsinya untuk belanja pegawai daripada belanja modal. Hal tersebut inilah yang dapat mengakibatkan pembangunan yang ada pada daerah belum terlihat signifikan dalam hal peningkatan kesejahteraan masyarakat dan masih minimnya kualitas pelayanan kepada publik.

Dari fenomena yang telah penulis uraikan di atas, maka penulis tertarik melakukan penelitian mengenai "Pengaruh Pendapatan Asli Daerah (PAD), dan Dana Alokasi Khusus (DAK) Terhadap Alokasi Belanja Modal Pada Kabupaten/Kota Pemerintah Provinsi Aceh Tahun 2014-2018”.

\section{TINJAUAN PUSTAKA \\ LANDASAN TEORITIS}

Teori keagenan menyatakan bahwa hubungan keagenan merupakan sebuah persetujuan (kontrak) di antara dua pihak yaitu prinsipal dan agen, dimana prinsipal memberi wewenang kepada agen untuk mengambil keputusan atas nama prinsipal (Jensen dan Meckling 1976 dalam Yovita 2011). Dalam teori keagenan terdapat perbedaan kepentingan antara agen dan prinsipal, sehingga mungkin saja pihak agen tidak selalu melakukan tindakan terbaik bagi kepentingan prinsipal. Scott (2000) dalam Bangun (2009) menjelaskan bahwa teori keagenan merupakan cabang dari game theory yang mempelajari suatu model kontraktual yang mendorong agen untuk bertindak bagi prinsipal saat kepentingan agen bisa saja bertentangan dengan kepentingan prinsipal. Prinsipal pendelegasikan pertanggung jawaban atas pengambilan keputusan kepada agen, dimana wewenang dan tanggung jawab agen maupun prinsipal diatur dalam kontrak kerja atas persetujuan bersama.

Keterkaitan teori keagenan dengan penelitian ini yaitu hubungan antara pemerintah pusat dengan pemerintah daerah dalam penyaluran dana perimbangan dan hubungan antara masyarakat yang diproksikan oleh DPRD (prinsipal) dengan pemerintah daerah (agen) (Ardiansyah, 2014). Penggunaan dana perimbangan dari pemerintah pusat diserahkan sepenuhnya kepada pemerintah daerah, 
dengan tujuan untuk membantu pemerintah daerah untuk mendanai kebutuhan daerah.

\section{Belanja Modal}

Dalam Peraturan Menteri Keuangan Nomor 91/PMK.06/2007 tentang Bagan Akun Standar bahwa belanja modal yaitu pengeluaran pendapatan anggaran digunakan untuk memperoleh atau menambah aset tetap/aset lainnya yang dapat memberikan keuntungan lebih dari satu tahun atau melebihi batasan minimal kapitalisasi aset tetap atau aset lainnya yang ditelah ditentukan oleh pemerintah untuk dipergunakan dalam operasional kegiatan sehari-hari.

Menurut (Kusufi \& Halim, 2012:107) belanja modal yaitu pengeluaran anggaran untuk memperoleh aset lainnya yang dapat memberikan keuntungan lebih dari satu periode akuntansi. Belanja modal termasuk belanja tanah, belanja peralatan dan mesin, belanja gedung dan bangunan, belanja jalan, irigasi, dan jaringan, dan belanja aset tetap lainnya.

Menurut (Halim, 2007:101) belanja modal adalah pengeluaran anggaran untuk mendapatkan aset tetap dan aset lainnya yang dapat memberikan keuntungan lebih dari satu periode akuntansi. Cara untuk memperoleh belanja modal dengan menggunakan proses lelang atau tender. Aset tetap yang dimiliki oleh pemerintah daerah merupakan suatu syarat untuk adanya belanja modal yang dapat memberi pelayanan kepada publik. Untuk meningkatkan aset tetap pemerintah daerah harus mengalokasikan dana dalam bentuk anggaran belanja modal dapat disebut sebagai Anggaran Pendapatan dan Belanja Kabupaten (APBK). Setiap tahun adanya pengadaan aset tetap oleh pemerintah daerah sehingga dapat memberikan dampak jangka panjang secara finansial (Ardhani, 2011).

Belanja modal dapat diklasifikasikan dalam 5 (lima) kategori utama Syaiful dalam (Yovita, 2011) sebagai berikut:

1. Belanja Modal Tanah

Belanja modal tanah merupakan pengeluaran/biaya yang digunakan untuk pengadaan/pembelian/pembelian/pembebas an penyelesaian, balik nama serta sewa tanah, pengosongan, pengurungan lainnya sehubungan dengan perolehan hak atas tanah dan sampai tanah dimaksud dalam kondisi siap pakai.

2. Belanja Modal Peralatan dan Mesin Belanja modal peralatan dan mesin merupakan pengeluaran/biaya digunakan pengadaan/penambahan/pengantian, dan peningkatan kapasitas peralatan mesin serta inventaris kantor yang dapat memberikan manfaat lebih dari 12 (dua belas) bulan dan sampai peralatan dan mesin dalam keadaan siap pakai.

3. Belanja Modal Gedung dan Bangunan Belanja modal gedung dan bangunan merupakan pengeluaran/biaya digunakan untuk pengadaan/penambahan, termasuk untuk perencanaan, pemeriksaan dan pengelolaan dalam pembangunan gedung dan bangunan dimaksud dalam kondisi yang siap dipakai.

4. Belanja Modal Jalan, Irigasi dan Jaringan

Belanja modal jalan, irigasi dan jaringan merupakan pengeluaran/biaya dalam pengadaan/penambahan/penggantian/pening katan pembangunan/pembuatan serta perawatan, termasuk pengeluaran untuk perencanaan, pemeriksaan pengelolaan jalan irigasi dan jaringan yang menambah kapasitas sampai jalan irigasi dan jaringan dimaksud dalam kondisi siap pakai.

5. Belanja Modal Fisik Lainnya

Belanja modal fisik lainnya merupakan pengeluaran/biaya dilakukan didalam pengadaan/penambahan/penggantian/peningkatan/pembangunan dan perawatan fisik lainnya yang tidak termasuk dalam kriteria belanja modal tanah, peralatan, mesin, gedung, bangunan, jalan irigasi dan jaringan, dan kemudian belanja modal kontrak sewa beli, pembelian barang-barang kesenian, buku-buku dan jurnal ilmiah.

\section{Pendapatan Asli Daerah}

Menurut (Nurcholis, 2007:182) pendapatan asli daerah (PAD) merupakan penerimaan pendapatan yang dipungut melalui peraturan daerah yang sesuai dengan undang-undang yang berlaku bersumber dari pajak daerah, retribusi daerah, laba perusahaan daerah dan lain-lain pendapatan asli daerah yang sah. Pendapatan daerah merupakan kewenangan daerah yang diakui sebagai penambah dari nilai kekayaan bersih melalui periode anggaran tertentu.

Dalam Undang-Undang Nomor 32 Tahun 2004 tentang pemerintahan daerah, pendapatan suatu daerah berasal dari dana perimbangan dan dari daerah itu sendiri. Sedangkan dalam Undang-Undang Nomor 33 Tahun 2004 tentang Perimbangan Keuangan Antara Pusat dan Daerah bahwa pendapatan asli daerah mengemukakan bahwa penerimaan pendapatan yang diperoleh daerah dari sumber daerahnya sendiri yang dipungut melalui peraturan daerah yang sesuai dengan peraturan perundangundangan.

Adapun sumber-sumber pendapatan asli daerah yang diatur dalam Undang-Undang Nomor 32 Tahun 2004 tentang Pemerintahan Daerah yaitu :

1. Pajak Daerah

Hasil pajak daerah merupakan pungutan daerah yang bersumber dari peraturan perundang-undangan, sifatnya memaksa dan tidak mendapatkan bayaran secara langsung. Pajak daerah yaitu tarif yang dilakukan oleh pemerintah daerah dan hasilnya digunakan untuk keperluan daerah 
untuk kemakmuran rakyatnya yang balas jasanya tidak langsung diberikan. Sedangkan pelaksanaannya langsung dipaksakan.

2. Retribusi Daerah

Hasil retribusi daerah yaitu pungutan daerah sebagai pembayaran yang telah secara sah menjadi pembayaran atas pemakaian karena mendapat jasa dari pekerjaan, usaha atau milik pemerintah daerah yang bersangkutan. Retribusi daerah mempuyai sifat- sifat yaitu pelaksanaanya bersifat ekonomis dimana adanya imbalan langsung walaupun harus memenuhi persyaratan-persyaratan formil maupun materil, tetapi ada juga alternatif untuk tidak ingin membayar yaitu pungutan yang sifatnya tidak diketahui dalam hal-hal tertentu. Retribusi daerah adalah pengembalian biaya yang telah dilakukan oleh pemerintah daerah untuk memenuhi permintaan anggota masyarakat.

3. Hasil Pengelolaan Kekayaan Daerah Yang Dipisahkan

Hasil perusahaan milik daerah adalah anggaran pendapatan daerah dari laba bersih perusahaan daerah berupa dana dalam meningkatkan pembangunan daerah dan bagian anggaran bagi belanja daerah yang dimiliki oleh daerah, baik dari perusahaan daerah yang dipisahkan dan sesuai dengan motif pendirian dan pengelolaan. Maka perubahan daerah merupakan suatu kesatuan produksi yang dapat meningkatkan pendapat daerah, memberikan jasa, menyelenggarakan kemanfaatan umum, dan perekonomian daerah.

4. Lain-Lain Pendapatan Asli Daerah Yang Sah

Lain-lain pendapatan asli daerah yang sah merupakan pendapatan yang tidak termasuk dalam jenis pajak daerah, restibusi daerah, dan pendapatan dari dinas-dinas. Lain-lain usaha daerah yang sah mempunyai sifat pembuka dalam bentuk pemerintah daerah untuk melakukan kegiatan yang menghasilkan baik itu berupa materi dalam kegiatan dengan cara-cara yag wajar dan tidak menyalahi peraturan yang memiliki tujuan dalam menunjang, melapangkan, dan memantapkan suatu kebijakan daerah disuatu bidang tertentu.

\section{Dana Alokasi Khusus}

Menurut Ikhlas dalam (Misbahuddin, 2018:19) dana alokasi khusus adalah salah satu mekanisme transfer keuangan pemerintah pusat antar pemerintah daerah yang bertujuan untuk meningkatkan penyediaan sarana dan prasarana fisik daerah sesuai prioritas nasional dan untuk mengurangi kesenjangan laju pertumbuhan antara daerah dan pelayanan dalam bidang. Dana alokasi khusus (DAK) memiliki peran penting dalam mendorong percepatan pembangunan daerah dan pelayanan dasar daerah karena sesuai dengan prinsip desentralisasi tanggung jawab dan akuntabilitas bagi penyediaan pelayanan dasar masyarakat yang telah dialihkan kepada pemerintah daerah (Ikhlas, 2011)

Dalam Peraturan Pemerintah Nomor 55 Tahun 2005 tentang Dana Perimbangan pada Pasal 1 Ayat 24 mendefinisikan bahwa dana alokasi khusus (DAK) yaitu dana yang bersumber dari pendapatan APBN yang dialokasikan untuk daerah tertentu dan membantu membiayai kebutuhan tertentu yang merupakan urusan daerah dan sesuai dengan prioritas nasional.

Menurut (Yani, 2008:172) mendefinisikan bahwa dana alokasi khusus diarahkan kepada daerah tertentu untuk dialokasikan pada kebutuhan tertentu yang merupakan bagian dari program yang menjadi salah satu prioritas daerah. Dana alokasi khusus membantu daerah dan dapat mendanai kebutuhan fisik baik itu dalam sarana dan prasarana yang merupakan salah satu prioritas nasional dibidang antara lain pendidikan, kesehatan, infrastruktur (irigasi, jalan dan air bersih), kelautan/perikanan, pertanian, prasarana dari pemerintah daerah, dan lingkungan hidup.

Berdasarkan dari pendapat diatas, maka dapat disimpulkan bahwa dana alokasi khusus (DAK) adalah dana yang bersumber dari pendapatan APBN yang diarahkan kepada daerah tertentu untuk membiayai kegiatan khusus yang merupakan bagian dari program yang menjadi salah satu prioritas daerah dalam hal kepentingan sarana dan prasarana pelayanan masyarakat yang belum mencapai standar tertentu dalam mendorong percepatan pembangunan ekonomi.

\section{Hubungan Antara Pendapatan Asli Daerah dengan Belanja Modal}

Pendapatan asli daerah (PAD) adalah semua sumber pembiayaan bagi pemerintah daerah dalam menciptakan infrastruktur daerah. Pendapatan asli daerah berasal dari sumber ekonomi asli daerah yaitu pajak daerah, retribusi daerah, pengelolaan kekayaan daerah yang dipisahkan dan lain-lain Pendapatan asli daerah yang sah. Sementara itu dalam masa desentralisasi sekarang ini, pemerintah daerah harus mampu dalam mengembangkan dan meningkatkan pendapatan asli daerahnya dengan memaksimalkan sumberdaya yang dimiliki supaya bisa membiayai segala kegiatan pencapaian infrastruktur sarana dan prasarana daerah melalui alokasi belanja modal pada APBD. Semakin baik pendapatan asli daerah suatu daerah tersebut maka semakin besar pula alokasi belanja modalnya (Ardhani, 2011).

Menurut (Halim, 2007) belanja modal merupakan pengeluaran anggaran yang dilakukan untuk pembentukan modal aset tetap dan aset lainnya yang memberi manfaat lebih dari satu periode 
akuntansi. Belanja modal dapat meliputi antara lain yaitu belanja tanah, bangunan dan gedung, peralatan dan aset tak berwujud.

Dalam pelaksanaan otonomi daerah, pemerintah daerah harus mampu memiliki sumber keuangan yang memadai untuk dapat membiayai pengeluaran daerahnya sendiridalam meningkatkan pembangunan. Keuangan pemerintah daerah dapat menentukan mampu atau tidaknya daerah dalam melaksanakan tugas dan fungsinya (Mamuka \& Inggriani, 2014). (Jaya \& Dwirandra, 2014) mengungkapkan bahwa pendapatan asli daerah (PAD) yang tinggi akan digunakan oleh pemda untuk memberikan pelayanan kepada publik dan kesejahteraan kepada masyarakat, maka pemda harus menggali pendapatan asli daerah (PAD) yang sebesarbesarnya sehingga dapat meningkatkan belanja modal.

\section{Hubungan Antara Dana Alokasi Khusus dengan Belanja Modal \\ Dalam Undang-Undang Nomor 33 Tahun}

2004 tentang perimbangan keuangan antara pemerintah pusat dengan pemerintah daerah adalah yang menjadi salah satu perwujudan pelaksanaan otonomi daerah adalah desentralisasi. Pelaksanaan desentralisasi dilakukan oleh pemerintah pusat dengan memberikan wewenang kepada pemerintah daerah untuk mengatur sendiri urusan dalam pemerintahnya. Kepentingan pemerintah pusat diserahkan kepada pemerintah daerah disertai dengan penyerahan keuangan yang terwujud dalam hubungan keuangan antara pemerintah pusat dengan pemerintah daerah.

Dana perimbangan merupakan perwujudan hubungan keuangan antara pemerintah pusat dengan pemerintah daerah. Salah satu dana perimbangan adalah dana alokasi khusus yang merupakan danayang bersumber dari pendapatan APBN yang dialokasikan kepada pemerintah daerah untuk membiayai kegiatan khusus yang merupakan prioritas dari daerah dan nasional. Dana alokasi khusus memiliki tujuan untuk mengurangi beban biaya dalam kegiatan khusus yang harus ditanggung pemerintah daerah. Pemanfaatan dana alokasi khusus dialokasikan kepada kegiatan investasi pembangunan, pengadaan, peningkatan, perbaikan terhadap sarana dan prasarana fisik pelayanan publik dengan umur ekonomis panjang, dengan diarahkan pemanfaatan DAK untuk kegiatan tersebut sehingga dapat meningkatkan pelayanan kepada publik yang direalisasikan dalam belanja modal (Ardhani, 2011).

Penelitian yang dilakukan oleh Anggia Situngkir (2009) dalam (Wandira, 2013) dana alokasi khusus (DAK) berpengaruh positif dan signifikan terhadap anggaran belanja modal. Sementara lembaga SMERU menyatakan bahwa dana alokasi khusus adalah salah satu yang menjadi sumber pendanaan untuk belanja modal. Hal ini mengindikasikan bahwa terdapat hubungan antara pemberian dana transfer dari pemerintah pusat dana alokasi khusus dengan alokasi anggaran pengeluaran daerah melalui belanja modal.

\section{Kerangka Konseptual}

Adapun kerangka konseptual dalam penelitian ini adalah sebagai berkut:

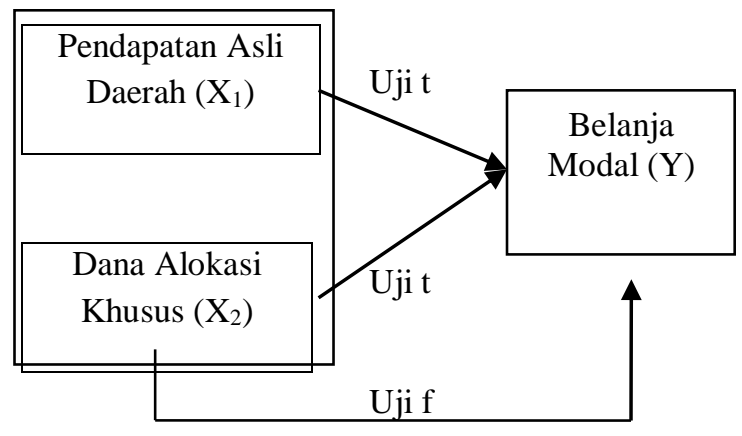

\section{Gambar 1 \\ Kerangka Konseptual}

\section{Hipotesis}

Berdasarkan landasan teori dan pemaparan kerangka konseptual maka hipotesis yang akan diajukan sebagai berikut:

H1 : Pendapatan Asli Daerah (PAD) berpengaruh terhadap Alokasi Belanja Modal pada Kabupaten/Kota di Provinsi Aceh Tahun 20142018.

H2 : Dana Alokasi Khusus (DAK) berpengaruh terhadap Alokasi Belanja Modal pada Kabupaten/Kota di Provinsi Aceh Tahun 20142018.

H3 : Pendapatan Asli Daerah (PAD) dan Dana Alokasi Khusus (DAK) berpengaruh terhadap Alokasi Belanja modal pada Kabupaten/Kota di Provinsi Aceh Tahun 2014-2018.

\section{METODE PENELITIAN \\ Objek Penelitian}

Objek Penelitian adalah aspek yang ingin diteliti dalam penelitian, yang menjadi objek penelitian yaitu Pendapatan Asli Daerah (PAD), Dana Alokasi Khusus (DAK), dan Belanja Modal. Lokasi penelitian ini yaitu pada Kabupaten/Kota di Provinsi Aceh Tahun 2014-2018.

\section{Data dan Sumber Data \\ Data}

Data yang dikumpulkan dalam penelitian ini adalah data sekunder. Data sekunder merupakan sumber data penelitian yang diperoleh peneliti secara tidak langsung atau yang diperoleh dan dikumpul oleh pihak lain (Kuncoro, 2013:148). Data sekunder dalam penelitian ini adalah data berupa Laporan Realisasi Anggaran Pendapatan dan Belanja Kabupaten (APBK) Pemerintah yang terdiri dari data realisasi Pendapatan Asli Daerah (PAD), dan Dana 
Alokasi Khusus (DAK) data realisasi belanja modal Provinsi Aceh tahun 2014-2018.

\section{Sumber Data}

Data penelitian yang penulis gunakan dalam penelitian ini adalah berupa data sekunder dan bersifat kuantitatif (numerical). Dalam penelitian ini, peneliti menggunakan data time series selama 5 (lima) tahun, yaitu sekumpulan data untuk meneliti suatu fenomena tertentu yang dilakukan secara berulang-ulang dalam waktu tertentu (time series). Data diperoleh melalui website Direktorat Jenderal Perimbangan Keuangan Kementrian Keuangan Republik Indonesia www.djpk.kemenkeu.go.id.

\section{Metode Pengumpulan Data}

Pada penelitian ini metode pengumpulan data yang digunakan dalam penelitian ini merupakan metode dokumentasi. Metode ini digunakan untuk memperoleh data mengenai data pendapatan asli daerah, dana alokasi khusus, dan belanja modal dimana data yang digunakan dari laporan Realisasi Anggaran Pendapatan dan Belanja Kabupaten (APBK) di Provinsi Aceh tahun 2014-2018 yaitu sebanyak 23 Kabupaten/Kota yang telah diterbitkan oleh Dirjen Kementrian Keuangan.

Model persamaan regresi yang akan diuji dalam penelitian ini adalah:

Keterangan:

$$
Y=\alpha+\beta 1 X_{1}+\beta 2 X_{2}+e
$$

$$
\begin{array}{ll}
\mathrm{Y} & =\text { Belanja Modal } \\
\alpha & =\text { Konstanta } \\
\beta 1, \beta 2 & =\text { Koefesien Korelasi } \\
\mathrm{X}_{1} & =\text { Pendapatan Asli Daerah } \\
\mathrm{X}_{2} & =\text { Dana Alokasi Khusus } \\
\mathrm{e} & =\text { Error Term. }
\end{array}
$$

\section{HASIL PENELITIAN DAN PEMBAHASAN Uji Normalitas}

Gambar 2. Grafik Normal Probability Plot

Normal P-P Plot of Regression Standardized Residual

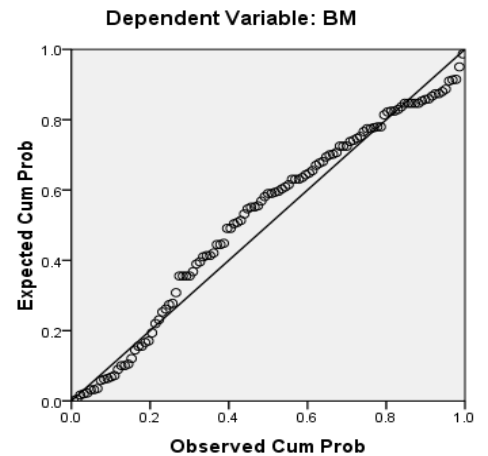

Deteksi data berdistribusi normal atau tidak peneliti melakukannya dengan menggunakan grafik normal probability plot dimana distribusi normal akan membentuk satu garis lurus diagonal, dan plooting data akan dibandingkan dengan garis diagonal. Jika distribusi data adalah normal, maka garis yang menggambarkan data sesungguhnya akan mengikuti garis diagonal. Dalam penelitian ini grafik normal probability plot menunjukkan bahwa model regresi layak di pakai dalam penelitian ini karena pada grafik normal P-Plot terlihat jika data menyebar disekitar garis diagonal dan mengikuti arah garis diagonal sehingga memenuhi asumsi normalitas.

\section{Uji Multikolinieritas}

Deteksi terdapat ada atau tidaknya multikolinieritas dapat dilihat dari tolerance dan variance inflation factor (VIF). Kriteria pengujian adalah apabila nilai tolerance $\geq 0,10$ dan nilai VIF $\leq$ 10, maka dapat diartikan bahwa tidak terdapat multikolinearitas pada penelitian tersebut. Dalam penelitian ini menemukan bahwa data tidak terdapat multikolinearitas ditujukan pada tabel hasil uji multikolinearitas dimana hasil perhitungan menunjukan bahwa nilai tolerance lebih besar dari 0,10 yang berarti tidak ada kolerasi antara variabel independen dan nilai variance inflation factor (VIF) juga menunjukkan nilai VIF lebih kecil dari 10.

Tabel 2.

Hasil Uji Multikolinieritas Coefficients ${ }^{a}$

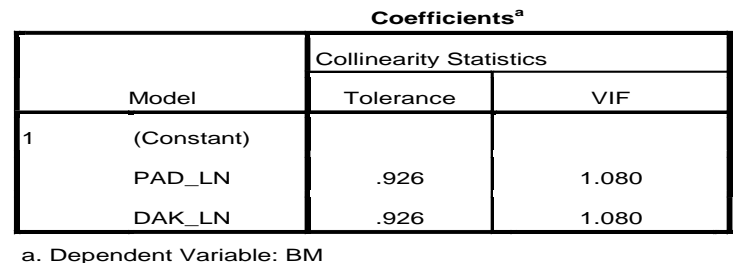

\section{Uji Autokorelasi}

Deteksi ada atau tidaknya autokorelasi dapat dilakukan dengan cara melihat nilai Durbin-Watson (D-W). Data dikatakan baik apabila nilai D-W dibawah -2 sampai +2 . Dalam penelitian ini dapat disimpulkan terdapat autokorelasi pada regres ini. Data terdapat autokorelasi ditunjukkan pada tabel hasil uji autokorelasi dimana hasil dalam penelitian menunjukan bahwa nilai D-W yaitu sebesar 0,742, nilai tersebut berada di antara -2 sampai 2 artinya terdapat autokorelasi pada regres ini. 
Tabel 3.

\section{Hasil Uji Autokeralasi}

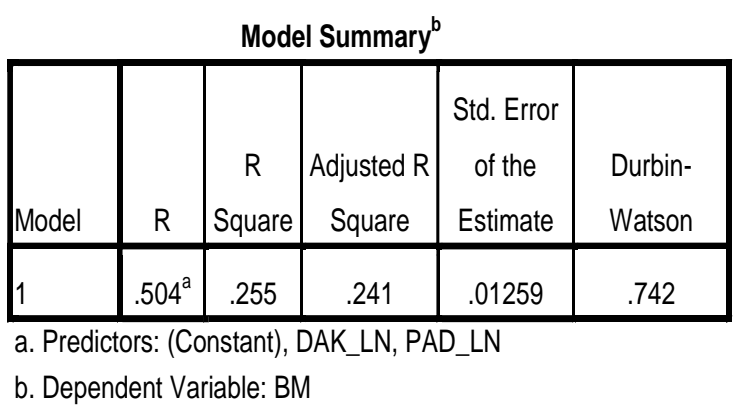

\section{Uji Heteroskedastisitas}

Deteksi ada atau tidaknya terjadi heteroskedastisitas dapat dilakukan dengan melihat ada atau tidaknya pola tertentu pada grafik scatterplot. Dalam penelitian ini menemukan bahwa tidak terjadinya heteroskedastisitas dilihat pada gambar hasil uji heteroskedastisitas dimana dalam penelitian ini menunjukkan bahwa data (titik-titik menyebar secara merata diatas dan di bawah titik nol, tidak berkumpul di satu tempat, serta tidak membentuk pola tertentu sehingga dapat disimpulkan bahwa pada uji regresi ini tidak terjadi heteroskedastisitas.

\section{Gambar 3.}

Hasil Uji Heteroskedastisitas

Scatterplot

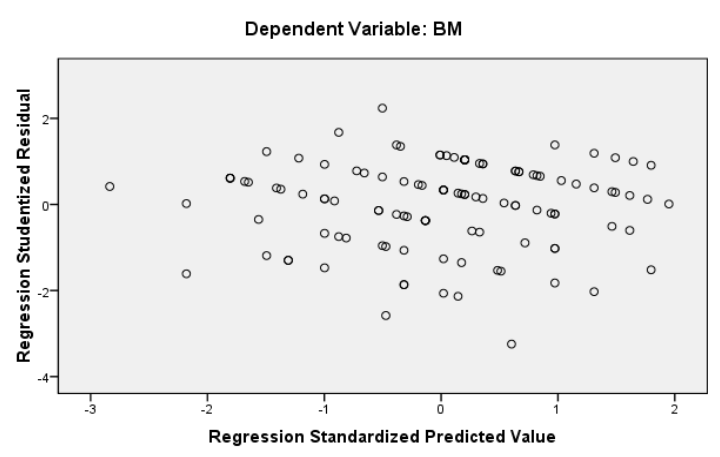

\section{Pengujian Hipotesis}

Tabel 4.

Hasil Analisis Regresi Linear Berganda

\begin{tabular}{|c|c|c|c|c|}
\hline & & & & oefficients ${ }^{a}$ \\
\hline \multirow[b]{2}{*}{ Model } & & \multicolumn{2}{|c|}{$\begin{array}{c}\text { Unstandardized } \\
\text { Coefficients }\end{array}$} & $\begin{array}{c}\text { Standardized } \\
\text { Coefficients }\end{array}$ \\
\hline & & B & Std. Error & Beta \\
\hline \multirow[t]{3}{*}{1} & (Constant) & 1.899 & .228 & \\
\hline & PAD_LN & .363 & .158 & .195 \\
\hline & DAK_LN & .800 & .163 & .416 \\
\hline
\end{tabular}

a. Dependent Variable: BM

Berdasarkan hasil analisis regresi pada tabel diatas, maka dapat disususn persamaan regresi sebagai berikut:

$$
Y=1.899+0.363 X_{1}+0.800 X_{2}
$$

Uji t

Tabel 5.

Hasil pengujian Parsial

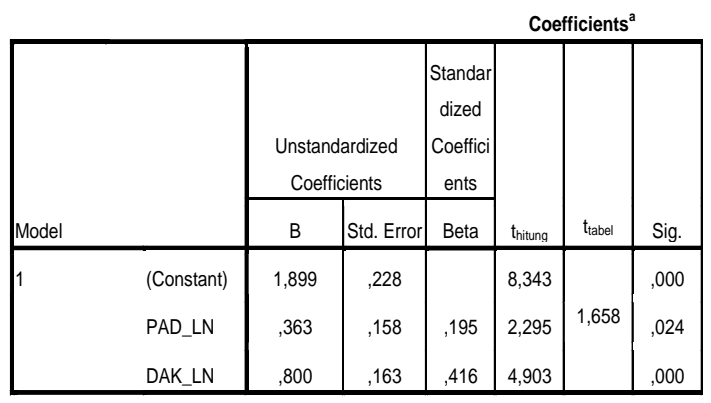

a. Dependent Variable: BM

Berdasarkan tabel diatas dapat dinyatakan bahwa nilai thitung untuk pendapatan asli daerah (X1) sebesar 2,295 > $t_{\text {tabel }}$ sebesar 1,658 dan memiliki tingkat signifikan sebesar $0,024<$ dari tingkat signifikan 0,05, maka kesimpulannya $\mathrm{H}_{1}$ diterima. Artinya secara parsial pendapatan asli daerah berpengaruh signifikan terhadap alokasi belanja modal pada Kabupaten/Kota di Provinsi Aceh tahun 2014-2018.

Berdasarkan tabel diatas dapat dinyatakan bahwa nilai thitung untuk dana alokasi khusus (X2) sebesar 4,903> $\mathrm{t}_{\text {tabel }}$ sebesar 1,658 dan memiliki tingkat signifikan sebesar $0,000<$ dari tingkat signifikan 0,05, maka kesimpulannya $\mathrm{H}_{2}$ diterima. Artinya secara parsial dana alokasi khusus berpengaruh signifikan terhadap alokasi belanja modal pada Kabupaten/Kota di Provinsi Aceh tahun 2014-2018. 
Uji F

Tabel 6.

Hasil Pengujian Regresi Simultan

\begin{tabular}{|c|c|c|c|c|c|c|c|}
\hline & & & & & \multicolumn{3}{|c|}{ ANOVA $^{\circ}$} \\
\hline \multicolumn{2}{|c|}{ Model } & $\begin{array}{l}\text { Sum of } \\
\text { Squares }\end{array}$ & Df & $\begin{array}{c}\text { Mean } \\
\text { Square }\end{array}$ & $F_{\text {hitung }}$ & $F_{\text {tabel }}$ & Sig. \\
\hline \multirow[t]{3}{*}{1} & Regression & ,006 & 2 & ,003 & \multirow[t]{3}{*}{19,119} & 3,08 & \multirow[t]{3}{*}{, $000^{\mathrm{a}}$} \\
\hline & Residual & ,018 & 112 & , 000 & & & \\
\hline & Total & ,024 & 114 & & & & \\
\hline
\end{tabular}

a. Predictors: (Constant), DAK_LN, PAD_LN

b. Dependent Variable: BM

Berdasarkan tabel di atas menunjukkan bahwa nilai $F_{\text {hitung }}$ untuk variabel pendapatan asli daerah (X1) dan dana alokasi khusus (X2) sebesar 19,119> $\mathrm{F}_{\text {tabel }}$ sebesar 3.08 dan memiliki tingkat signifikan sebesar $0,000<$ dari tingkat signifikan 0,05 , maka kesimpulannya $\mathrm{H}_{3}$ diterima. Artinya secara simultan pendapatan asli daerah dan dana alokasi khusus berpengaruh dan signifikan terhadap alokasi belanja modal pada Kabupaten/Kota di Provinsi Aceh tahun 2014-2018.

\section{Koefisien Determinasi}

Tabel 7.

Koefisien Determinasi

Model Summary ${ }^{b}$

Model Summary

\begin{tabular}{|c|c|c|c|}
\hline Model & R & R Square & Adjusted R Square \\
\hline 1 &, $504^{\mathrm{a}}$ &, 255 &, 241 \\
\hline
\end{tabular}

a. Predictors: (Constant), DAK_LN, PAD_LN

b. Dependent Variable: BM

Berdasarkan tabel di atas menyatakan bahwa nilai $\mathrm{R}^{2}$ sebesar 0,255 atau $25,5 \%$. Hal ini menunjukkan bahwa sebesar $25,5 \%$ variabel dependen (alokasi belanja modal) dapat dijelaskan oleh dua variabel independen dalam penelitian ini yaitu pendapatan asli daerah dan dana alokasi khusus. Sedangkan sisanya sebesar $74,5 \%$ dipengaruhi oleh variabel lain yang tidak diteliti dalam penelitian ini. Adapun nilai $\mathrm{R}$ (koefisien korelasi) diperoleh nilai sebesar 0,504.

\section{PEMBAHASAN HASIL PENELITIAN}

\section{Pengaruh Pendapatan Asli Daerah Terhadap Alokasi Belanja Modal}

Secara parsial, variabel pendapatan asli daerah berpengaruh terhadap alokasi belanja modal pada Kabupaten/Kota di Provinsi Aceh Tahun 20142018. Hal ini ditunjukkan oleh hasil nilai signifikan yang dimiliki oleh pendapatan asli daerah sebesar $0,024<$ dari tingkat signifikan 0,05 , maka kesimpulannya pendapatan asli daerah berpengaruh terhadap alokasi belanja modal pada Kabupaten/Kota di Provinsi Aceh Tahun 2014-2018.

Pendapatan asli daerah memiliki hubungan antara pemerintah daerah dengan masyarakat. Masyarakat sebagai pihak prinsipal telah memberikan sumber daya kepada daerah berupa pembayaran pajak daerah, retribusi daerah dan lain sebagainya untuk dapat meningkatkan pendapatan asli daerah. Pemerintah daerah selaku agen dalam hal ini, sudah seharusnya memberikan timbal balik kepada masyarakat dalam bentuk pelayanan kepada publik yang memadai yang didanai oleh pendapatan asli daerah itu sendiri.

Penelitian sebelumnya yang dilakukan oleh Susanti (2015) memberikan hasil penelitian yang sama dengan penelitian ini yaitu pendapatan asli daerah berpengaruh terhadap belanja modal pada Kabupaten/Kota di Provinsi Aceh tahun 2011-2014. Kabupaten/Kota Pemerintah Provinsi Aceh dengan pendapatan asli daerah yang baik dan diikuti dengan peningkatan pendapatan asli daerah sehingga akan meningkatkan alokasi belanja modal pada kabupaten/Kota Provinsi Aceh. Berdasarkan hasil penelitian diatas, yaitu semakin besar Pendapatan Asli Daerah (PAD) yang diperoleh dan pemanfaatan dari pendapatan asli daerah yang benar membuat besaran dana yang disalurkan pemerintah daerah untuk melakukan belanja modal dapat menjadi besar. Hasil penelitian tersebut diperkuat dengan hipotesis pertama penelitian ini yang menyatakan bahwa pendapatan asli daerah berpengaruh signifikan terhadap alokasi belanja modal.

\section{Pengaruh Dana Alokasi Khusus Terhadap Alokasi Belanja Modal}

Secara parsial, variabel dana alokasi khusus berpengaruh terhadap alokasi belanja modal pada Kabupaten/Kota di Provinsi Aceh Tahun 2014-2018. Hal ini ditunjukkan oleh hasil nilai signifikan yang dimiliki oleh dana alokasi khusus sebesar $0,000<$ dari tingkat signifikan 0,05 , maka artinya dana alokasi khusus berpengaruh terhadap alokasi belanja modal pada Kabupaten/Kota Pemerintah Provinsi Aceh Tahun 2014-2018. Hasil ini menunjukkan bahwa semakin tinggi dana alokasi khusus maka belanja modal akan semakin meningkat, begitu pula sebaliknya jika semakin rendah dana alokasi khusus maka belanja modal akan semakin rendah. Hasil ini memberikan adanya indikasi yang kuat bahwa perilaku belanja modal akan sangat dipengaruhi dari sumber penerimaan DAK. Hasil penelitian ini mendukung penelitian yang dilakukan oleh Ramlan (2016) yang mengungkapkan bahwa dana alokasi khusus berpengaruh positif terhadap belanja modal.

Sesuai dengan teori keagenan sebagai landasan teori yang digunakan dalam penelitian ini, pemerintah daerah selaku pihak agen harus mampu dalam hal mempertanggungjawabkan tugasnya terhadap pemerintah pusat artinya pemerintah daerah 
harus mengelola dengan baik dana yang diberikan oleh pemerintah pusat selaku pihak prinsipal dengan menetapkan strategi yang baik pada investasi pembangunan, pengadaan, peningkatan dan perbaikan sarana dan prasarana fisik dengan umur ekonomis yang panjang, dan termasuk pengadaan sarana fisik penunjang.

Berdasarkan hasil penelitian di atas yaitu semakin besar dana alokasi khusus maka dapat menyebabkan semakin besar pula kegiatan alokasi belanja modal yang dilakukan oleh pemerintah daerah. Dengan demikian hipotesis kedua dari penelitian ini menyatakan bahwa dana alokasi khusus berpengaruh signifikan terhadap alokasi belanja modal.

\section{Pengaruh Pendapatan Asli Daerah dan Dana Alokasi Khusus Terhadap Alokasi Belanja Modal}

Pengujian secara simultan menunjukkan bahwa pendapatan asli daerah, dana alokasi khusus secara bersama-sama berpengaruh terhadap alokasi belanja modal pada Kabupatn/Kota di Provinsi Aceh tahun 2014-2018. Hal ini ditunjukkan oleh nilai signifikan sebesar 0,000 < dari tingkat signifikan 0,05, maka kesimpulannya $\mathrm{H}_{3}$ diterima. Artinya secara simultan pendapatan asli daerah dan dana alokasi khusus berpengaruh dan signifikan terhadap belanja modal pada Kabupaten/Kota di Provinsi Aceh tahun 2014-2018.

Penelitian sebelumnya yang dilakukan oleh pelealu (2012). Hasil penelitian secara simultan pendapatan asli daerah dan dana alokasi khusus berpengaruh dan signifikan terhadap belanja modal. karena pendapatan asli daerah merupakan sumber pembiayaan bagi pemerintah daerah dalam menciptakan infrastruktur daerah. Pendapatan asli daerah (PAD) didapatkan dari hasil pajak daerah, hasil retribusi daerah, hasil pengelolaan kekayaan daerah yang dipisahkan dan lain-lain pendapatan asli daerah yang sah.

Pemerintah daerah dapat menggunakan dana alokasi khusus untuk memberikan pelayanan kepada publik yang direalisasikan dalam belanja modal. Dana alokasi khusus memiliki peran penting dalam dinamika pembangunan sarana dan prasarana pelayanan dasar di daerah karena sesuai dengan prinsip desentralisasi tanggung jawab dan akuntabilitas bagi penyediaan pelayanan dasar masyarakat yang telah ditetapkan kepada pemerintah daerah. Tujuan dana alokasi khusus yaitu untuk mengurangi beban biaya kegiatan khusus yang harus ditanggung oleh pemerintah daerah. Berdasarkan dari hasil penelitian diatas maka hipotesis ketiga menyatakan bahwa pendapatan asli daerah (PAD) dan dana alokasi khusus (DAK) secara bersamasama berpengaruh signifikan terhadap belanja modal.

\section{PENUTUP \\ KESIMPULAN}

Dari hasil penelitian mengenai pengaruh Pendapatan Asli Daerah (PAD) dan Dana Alokasi Khusus (DAK) terhadap Alokasi Belanja Modal pada Kabupaten/Kota di Provinsi Aceh tahun 2014-2018, maka dapat diambil kesimpulan sebagai berikut:

1. Secara parsial, nilai signifikan thitung untuk pendapatan asli daerah sebesar 2,295> $t_{\text {tabel }}$ sebesar 1,658 dan memiliki tingkat signifikan sebesar 0,024 < dari tingkat signifikan 0,05, maka kesimpulannya $\mathrm{H}_{1}$ diterima. Dengan demikian, hasil dalam penelitian ini menemukakan bahwa secara parsial variabel pendapatan asli daerah berpengaruh signifikan terhadap alokasi belanja modal pada Kabupaten/Kota di Provinsi Aceh tahun 2014-2018.

2. Secara parsial, nilai signifikan thitung untuk dana alokasi khusus sebesar 4,903 > $t_{\text {tabel }}$ sebesar 1,658 dan memiliki tingkat signifikan sebesar 0,000< dari tingkat signifikan 0,05, maka kesimpulannya $\mathrm{H}_{2}$ diterima. Dengan demikian, hasil dalam penelitian ini menemukakan bahwa secara parsial dana alokasi khusus berpengaruh signifikan terhadap alokasi belanja modal pada Kabupaten/Kota di Provinsi Aceh tahun 20142018.

3. Secara simultan nilai signifikan $F_{\text {hitung }}$ untuk variabel pendapatan asli daerah dan dana alokasi khusus sebesar 19,119> $\mathrm{F}_{\text {tabel }}$ sebesar 3.08 dan memiliki tingkat signifikan sebesar $0,000<$ dari tingkat signifikan 0,05, maka kesimpulannya $\mathrm{H}_{3}$ diterima. Dengan demikian, hasil dalam penelitian ini menemukakan bahwa secara simultan pendapatan asli daerah dan dana alokasi khusus berpengaruh dan signifikan terhadap alokasi belanja modal pada Kabupaten/Kota di Provinsi Aceh tahun 2014-2018.

\section{SARAN}

Berdasarkan hasil pembahasan dan kesimpulan mengenai pengaruh Pendapatan Asli Daerah dan Dana Alokasi Khusus terhadap Alokasi Belanja Modal pada Kabupaten/Kota di Provinsi Aceh tahun 2014-2018, maka saran yang dapat dikemukakan adalah sebagai berikut:

1. Variabel yang digunakan dalam penelitian yang akan datang diharapkan lebih lengkap dan lebih bervariasi, dengan menambah variabel independen lain baik ukuran-ukuran atau jenis-jenis penerimaan pemerintah lainnya, maupun variabel non keuangan seperti penerimaan pembiayaan dan pertumbuhan ekonomi. 
2. Penelitian selanjutnya dapat menggunakan rentang waktu data lebih dari lima tahun agar hasilnya dapat lebih menggambarkan kondisi yang ada dan memberikan hasil yang lebih komprehensif.

\section{KETERBATASAN}

Dalam penyusunan skripsi ini, terdapat beberapa keterbatasan yang mambatasi penulis diantaranya yaitu:

1. Segala akses kampus ditutup selama terjadinya covid-19.

2. Dalam keadaan pandemi covid-19 yang terjadi selama ini mahasiswa akhir sangat kesulitan dalam segi bimbingan atau konsultasi yang dilakukan secara via online.

3. Peneliti hanya mengambil dua variabel independen yaitu, pendapatan asli daerah (PAD) dan dana alokasi khusus (DAK)

\section{DAFTAR PUSTAKA}

Ardhani, P. (2011). Pengaruh Pertumbuhan Ekonomi, Pendapatan Asli Daerah, Dana Alokasi Umum, Dan Dana Alokasi Khusus Terhadap Pengalokasian Anggaran Belanja Modal (Studi Pada Pemerintah Kabupaten/Kota Di Jawa Tengah)". Universitas Diponegoro.

Ardiansyah, Muhammad. 2014. "Pengaruh Corporate Governance, Leverage dan Profitabilitas Terhadap Manajemen Laba Pada Perusahaan Manufaktur Sektor Industri Barang Konsumsi Yang Terdaftar di BEI Periode 20092013”. (http://jurnal.umrah.ac.id/wpcontent/uploads/gravity_forms/1/, diakses tanggal 9 Maret 2015).

Bangun, Ricky Andra Levy (2009). "Pengaruh Dana Alokasi Khusus, Dana Alokasi Umum, dan Pendapatan Asli Daerah Terhadap Pendapatan Perkapita".Tesis, Universitas Sumatera Utara

Halim, A. (2007). Akuntansi Sektor Publik Akuntansi Keuangan Daerah. Salemba Empat.

Hendri Paulus Gerungan, Saerang, D. P. E., \& Ilat, V. (2015). Pengaruh pendapatan Asli Daerah, Dana Alokasi Umum, Dana Alokasi Khusus Terhadap Belanja Modal (Studi Kasus Pada Pemerintah Daerah Kabupaten dan Kota di Provinsi Sulawesi Utara). 1.

http://djpk.kemenkeu.go.id.
Ikhlas, S. (2011). Dana Alokasi Khusus dalam pembiayaan pembangunan.

Jaya, I. P. N. P. K., \& Dwirandra, A. A. N. . (2014). Pengaruh Pendapatan Asli Daerah Pada Belanja Modal dengan Pertumbuhan Ekonomi Sebagai Variabel Pemoderasi. Jurnal Akuntansi.

Kawendar, Warsito, Rohman, A., \& Handayani, S. (2008). Akuntansi Sektor Publik. Universitas Diponegoro.

Kuncoro, M. (2013). Metode Riset Untuk Bisnis dan Ekonomi. Erlangga.

Kusufi, \& Halim. (2012). Akuntansi Sektor Publik: “Akuntansi Keuangan Daerah. Salemba Empat.

Mamuka, V., \& Inggriani, E. (2014). Analisis Dana Transfer Pada pemerintah Daerah Kabupaten Kepulauan Talaud. EMBA, 2, 645-655.

Mardiasmo. (2009). Akuntansi Sektor Publik. Andi.

Misbahuddin. (2018). Pengaruh Pendapatan Asli Daerah (PAD) Dan Dana Perimbangan Terhadap Belanja Modal Pada Kabupaten/Kota Di Provinsi Aceh 2013-2015.

Nurcholis, H. (2007). Teori dan Praktik Pemerintahan dan Otonomi Daerah. Grasindo.

Undang-Undang Nomor 32 Tahun 2004 tentang Pemerintahan Daerah.

Undang Nomor 33 Tahun 2004 tentang Perimbangan Keuangan Daerah.

Undang-Undang Nomor 18 Tahun 2001 tentang Otonomi Khusus bagi Provinsi Daerah Istimewa Aceh.

Pelealu, A. M. (2012). Pengaruh Dana Alokasi Khusus (DAK), Dan Pendapatan Asli Daerah (PAD) Terhadap Belanja Modal Pemerintah Kota Manado Tahun 2003-2012. Jurnal EMBA, 1(4), 1189-1197.

Peraturan Pemerintah Nomor 71 Tahun 2010 tentang Standar Akuntansi Pemerintah.

Peraturan Menteri Keuangan Nomor 91/PMK.06/2007 tentang Bagan Akun Standar.

Peraturan Pemerintah Nomor 55 Tahun 2005 tentang Dana Perimbangan. 
Peraturan Pemerintah Nomor 12 Tahun 2019 tentang Pengelolaan Keuangan Daerah.

Susanti, Susi., dan Fahlevi, Heru. 2016. Pengaruh Pendapatan Asli Daerah, Dana Alokasi Umum dan Dana Bagi Hasil terhadap Belanja Modal. Jurnal Ilmiah Mahasiswa Ekonomi Akuntansi (JIMEKA), 1(1), hal.183-191.

Wandira, A. G. (2013). Pengaruh Pendapatan Asli Daerah (PAD), Dana Alokasi Umum (DAU), Dana Alokasi Khusus (DAK), Dan Dana Bagi Hasil (DBH) Terhadap Pengalokasian Belanja Modal (Studi Empiris pada Pemerintah Provinsi se Indonesia tahun 2012). Universitas Negeri Semarang.

Yani, A. (2008). Hubungan Keuangan Antara Pemerintah Pusat dan Daerah di Indonesia. Rajagrafindo Persada.

Yovita, F. M. (2011). Pengaruh Pertumbuhan Ekonomi, Pendapatan Asli Daerah dan Dana Alokasi Umum Terhadap Pengalokasian Anggaran Belanja Modal (Studi Empiris pada Pemerintah Provinsi Se Indonesia Periode 2008 - 2010. Diponegoro Jurnal Of Accounting. 
